\title{
Differences in the physiological response of inter- and subtidal Antarctic limpets Nacella concinna to aerial exposure
}

\author{
Ellen Weihe, Doris Abele* \\ Alfred Wegener Institute for Polar and Marine Research, Department of Shelf Sea Ecology, Am Handelshafen 12, \\ 27570 Bremerhaven, Germany
}

\begin{abstract}
Antarctic intertidal zones are extremely harsh environments, and the Antarctic limpet Nacella concinna is one of the most conspicuous components of the macrofauna, colonizing such areas at King George Island, South Shetlands. The limpet subpopulation encompasses an intertidal and a subtidal ecomorph; these differ with respect to shell height and inner volume. We studied morphological, behavioural and physiological traits that distinguish both $N$. concinna subpopulations. We found a higher volume to circumference ratio of intertidal versus subtidal limpets to go along with a drastically reduced loss of body water during air exposure in intertidal specimens. Smaller intertidal limpets were less susceptible to desiccation than larger individuals. Further, the intertidal snails avoided accumulation of anaerobic metabolites (succinate, lactate and propionate), whereas subtidal limpets switched to anaerobic fermentation when exposed to air for $>12 \mathrm{~h}$. Only acetate accumulated in both types of snails after $12 \mathrm{~h}$. Mean $\mathrm{pO}_{2}$ in shell water was higher in intertidal (2.6 kPa) than subtidal individuals $(1.3 \mathrm{kPa})$ when submersed under water, and only the intertidal snails appeared able to respire air on emersion. These differences document strong physiological diversification between shore levels and shell morphs in the Antarctic limpet subpopulation at King George Island.
\end{abstract}

KEY WORDS: Nacella concinna $\cdot$ Antarctic limpet · Air exposure $\cdot$ Water loss $\cdot$ Morphometry $\cdot$ Onset of anaerobic metabolism $\cdot \mathrm{pO}_{2}$-regulation

\section{INTRODUCTION}

The Antarctic limpet Nacella concinna (Strebel, 1908 ) is the main macrobenthic invertebrate colonizing maritime Antarctic and sub-Antarctic rocky intertidal shores south of $60^{\circ} \mathrm{S}$ (Davenport 1988). These highlatitude intertidal zones are extremely harsh environments, in which survival of sessile macro-invertebrates is severely challenged by freezing and icefoot in winter, and melt water runoff from thawing ice and snowfields, among other factors, in the summer season. Walker (1972) was the first to distinguish 2 different $N$. concinna shell morphs with different shore level distributions at Signy Island (South Orkneys), a phenomenon that has now been accepted as a common feature of all populations on the shores of the Antarctic Penin- sula and the nearby South Shetland and South Orkney archipelagos. The intertidal and shallow subtidal shell morph is found in the upper littoral, including the splash zone, and down to approximately $4 \mathrm{~m}$ water depth, and has a high, heavy and dense shell, whereas the deep subtidal morph has lighter and flatter shells and is found at depths $>4 \mathrm{~m}$ and down to $110 \mathrm{~m}$ (Davenport 1988).

These 2 shell and ecomorphs are considered as only 1 limpet species, which reproduces in the early spring in the subtidal (Stanwell-Smith \& Clarke 1998). The onset of the spring phytoplankton bloom seems to be a spawning cue (Stanwell-Smith \& Clarke 1998), and recruitment of the pelagic larvae occurs in subtidal areas, from where individuals migrate towards the intertidal during later life. Young limpets of $<20 \mathrm{~mm}$ 
shell length were described as being sensitive to desiccation (Walker 1972) and, therefore, confined to the subtidal (Kim 2001). Of the adult limpets $>20 \mathrm{~mm}$, those with heavier shells are described as a migratory ecomorph, moving seasonally between intertidal and subtidal shore levels (upshore in spring, downshore in autumn), whereas the other ecomorph forms a nonmigratory and permanently subtidal subpopulation (Davenport 1988, Brêthes et al. 1994). Recently, observations were made around Rothera Station (Adelaide Island) which indicate that intertidal Nacella concinna specimens are able to survive the Antarctic winter in rock crevices under the ice (Waller et al. 2006). The authors identified mean super cooling survival temperatures of around $-5^{\circ} \mathrm{C}$ for $N$. concinna and found significantly higher tolerance of intertidal compared to sublittoral limpets to experimental deep freezing.

Nacella concinna is a non-homing limpet of high mobility, which can crawl over extended distances including sandy spaces, reaching a maximum speed of $10 \mathrm{~mm} \mathrm{~s}^{-1}$ at $0^{\circ} \mathrm{C}$ (Davenport 1997). In line with the enhanced migratory mobility, $N$. concinna is of low tenacity, i.e. low adhesive forces to clamp to the substratum, if compared to temperate limpet species. Davenport (1988) compared tenacity in both shore level subpopulations and found higher adhesive force and closer contraction of the shell to the substratum during tidal emersion in the intertidal ecomorph, although differences did not reach significance. Based on his own ecophysiological investigations and an earlier paper on genetics by Beaumont \& Wei (1991), in which 5 polymorphic gene loci showed no genetic differentiation between both $N$. concinna subpopulations, Davenport (2001) concluded that 'there is no evidence of genetic or physiological differences between the 2 limpet morphotypes'.

In the light of the rapid climate warming that is happening in the maritime Antarctic, where air temperature means have risen by $2.5 \mathrm{~K}$ over the past $50 \mathrm{yr}$ (Turner et al. 2005), the question arises as to how Antarctic limpets will be able to cope with the rather dramatic environmental change in their intertidal habitat. Increased air temperature is not the only changing factor; however, increased temperature drives glacier melting, leading to intensified meltwater formation, surface freshening and an increase of inshore water temperatures in the upper 10 to $15 \mathrm{~m}$ of coastal surface water (Schloss et al. 2008). Moreover, increasing aerial warming will directly affect intertidal fauna during low tides. Warming of the shell will happen more rapidly in air-exposed limpets, and especially in the non-homing species, which cannot tightly contract its shell to the rocky substratum, leaving it prone to desiccation. Rapid environmental change may accelerate specific adaptation in the intertidal limpet subpopulation and thereby may add to a physiological diversification of both Nacella concinna subpopulations and may, eventually, cause genetic splitting of the subpopulation. Indeed, in a recent paper, Aranzamendi et al. (2008) used ISSR-PCR (InterSimple Sequence Repeats-polymerase chain reaction) markers for analysis of the genetic differentiation between both limpet morphotypes in Potter Cove, King George Island. For 1 out of 3 sites tested in Potter Cove, the authors came to the conclusion that the 2 morphotypes can be considered genetically distinct subpopulations that maintain only low levels of gene flow. The limpets can therefore be regarded as model species for the adaptive response of a stenothermal (narrow thermal tolerance window) and stenosmotic (low tolerance of osmotic variability) subtidal species, which, in colonizing shallow intertidal habitats, is increasingly challenged by ongoing rapid local climate change.

We conducted a multilevel study of the possible adaptive response of both Nacella concinna subpopulations to environmental challenge, testing their tolerance to air exposure and hypoxia. Intertidal limpets with their higher shell might better ventilate their inner shell environment than subtidal conspecifics. We hypothesized that this would lead to enhanced tolerance to air exposure. We present data from air exposure experiments with intertidal and subtidal $N$. concinna from King George Island. We investigated the extent of water loss upon prolonged aerial exposure and recorded the $\mathrm{pO}_{2}$ values maintained in the extrapallial water in the top of the shell in both ecomorphs during sub- and emersion. We further investigated tissue adenylate levels, as well as the accumulation of anaerobic metabolites, and recorded the changes of gill tissue $\mathrm{pH}$ over the duration of a $24 \mathrm{~h}$ experimental air exposure, to unravel possible differences in the metabolic response between both subpopulations.

\section{MATERIALS AND METHODS}

Limpet collection. Intertidal Nacella concinna were collected during low tide at Peñon 1, Potter Cove, King George Island, South Shetlands, on 2 occasions in November 2005 and 2007 during 2 subsequent expeditions. Parallel to the intertidal samplings, divers collected subtidal individuals in 13 to $15 \mathrm{~m}$ water depth in Potter Cove at about $1 \mathrm{~km}$ from the intertidal sampling location. All snails were immediately transferred to the aquarium of Dallmann Laboratory, Jubany Station, and held in aerated, $0^{\circ} \mathrm{C}$ cold seawater from the cove for between $10 \mathrm{~d}$ and 3 wk before air exposure experiments were started. In the aquaria both groups of limpets were maintained 
permanently submersed, so that any differences between intertidal and subtidal control groups were not due to acute exposure to different in situ conditions.

Morphometric differences between subpopulations. Shell morphometric parameters were recorded for 181 intertidal and 136 subtidal experimental individuals. Length $(L)$, width $(W)$ and height $(H)$ of the shells were measured to the nearest $0.01 \mathrm{~mm}$ using digital dial callipers. $L$ was determined as the maximum distance from the anterior to the posterior shell margin, $W$ as the maximum distance between the lateral shell margins, and $H$ as the vertical distance from the ventral margin to the apex of the shell.

From these data, circumference $(C)$ and inner volume $(V)$ were calculated as:

$$
C=2\left(L^{2} / 8+W^{2} / 8\right)^{0.5}
$$

and

$$
V=L W H / 12
$$

according to Lowell (1984). Steepness $(S)$ and roundness $(R)$ were calculated using:

$$
S=2 H /(L+W)
$$

and

$$
R=W / L
$$

according to Orton (1932) cf. Wallace (1972).

As statistical analyses, differences between shells of the 2 subpopulations were tested by $t$-test (GraphPad Prism 4) and an ANCOVA (GraphPad InStat 3) model for comparing shell volume to circumference or shell volume to wet mass relationships in the 2 subpopulations.

Experimental air exposure and determination of water loss. Air exposure experiments for analysis of water loss, anaerobic metabolites and tissue adenylate levels in both subpopulations were carried out in 2005 and 2007 following identical protocols. In 2007, an additional sampling point after $2 \mathrm{~h}$ air exposure was included, whereas in 2005, samples were taken after 0, 6,12 , and $24 \mathrm{~h}$ of air exposure only. Prior to air exposure, limpets were blotted dry with tissue paper, weighed and placed individually on small pre-weighed plastic dishes over silica drying pearls in a desiccator. For each experimental time group 10 intertidal or 8 subtidal individuals were exposed to air. The desiccator was placed in snow and covered with dark cloth to minimize the impact of light and wind and to keep temperatures at $0^{\circ} \mathrm{C}$. Experiments were started in the evening, as the limpets were observed to be more active during the day, when they left the dishes to crawl around in the desiccator.

Whole-animal wet mass was determined again after the incubations. Subsequently, the limpets were killed, and shell and shell-free soft body wet mass (SFWM) were determined separately for calculations of water loss during air exposure in each group. Water loss from the limpets' tissue was calculated as the percentage of shell-free wet mass ( $\%$ SFWM). Tissues (gills, foot, digestive gland) were snap frozen in liquid nitrogen for biochemical analysis. No individual died during air exposure.

As statistical analyses, effects of subpopulation (subtidal, intertidal), air exposure time (h) and individual body mass (SFWM) on water loss (arcsine-transformed percentage data) were examined by analysis of covariance (ANCOVA, SAS software JMP 5.0.1a). The BoxCox routine was applied to the data to achieve homogeneity of variance (Sokal \& Rohlf 1995). Multivariate outliers in the sample space (water loss, exposure time, body mass) were identified by Mahalanobis jackknife distances (Barnett \& Lewis 1994) and excluded from further analysis.

Measurements of oxygenation $\left(\mathrm{pO}_{2}\right)$ in shell water. Measurements of the $\mathrm{pO}_{2}$ in the limpets' shell water were carried out in a thermostated aquarium at $0^{\circ} \mathrm{C}$ and $34 \%$ salinity natural seawater, using a fibre optical system by PreSens (Precision Sensing). Optodes were calibrated to $100 \%$ air saturation with aerated seawater and to $0 \%$ using a saturated solution of ascorbic acid at $0^{\circ} \mathrm{C}$. Calibration was confirmed by measuring the $\mathrm{O}_{2}$ concentration by the Winkler method. Air saturation was recorded in shell water of experimental individuals at 5 min intervals, using TX-3 oxymeters and TX3_v520 software by PreSens. The digital data of oxygen saturation were saved as a text file and copied into Excel for data calculation. Percent data were converted to oxygen partial pressure $(\mathrm{kPa})$ before performing statistical analysis.

To insert the fibre optical oxygen sensor, a hole was drilled into the top of the shell of experimental individuals. The hole was covered with thin elastic latex foil (Rubber Dam, Heraeus Kulzer). This foil was covered with isolation material (Armaflex, Armacell) to avoid exchange with the outside water. To insert the fibre optodes, a hole was punched through the isolation material using an injection needle, and the optodes were implanted through the hole into a small, mediumfilled space in the upper shell. Individuals were exposed to cycles of submersion and emersion, starting with submersion for up to $10 \mathrm{~h}$. After 8 to $10 \mathrm{~h}$, the water was drained from the thermostated aquarium and the limpets were exposed to air for 6 to $8 \mathrm{~h}$, followed by a second period of submergence. Only 5 intertidal and 3 subtidal limpets received 2 cycles of air exposure. During air exposure temperature was maintained at $0^{\circ} \mathrm{C}$. In total, 8 intertidal $(L: 33.5 \pm 2.2$; $C: 91.3 \pm 6.1$ ) and 10 subtidal specimens ( $L: 46.5 \pm 5.1$; $C: 126.1 \pm 15.3$ ) were analysed. 
Analysis of the $\mathbf{p O}_{2}$ data. Effects of subpopulation (intertidal vs. subtidal) and exposure state (air vs. water) on $\mathrm{pO}_{2}$ were analysed using ANCOVA (SAS software JMP 5.0.1a), applying the full interaction model: $\mathrm{pO}_{2}=$ subpopulation $\times$ exposure state $\times$ exposure time.

Exposure time was set to zero at each change of exposure state (air-water-air). $\mathrm{pO}_{2}$ data were BoxCox-transformed (Sokal \& Rohlf 1995) to achieve normality and homogeneity of variances. The Tukey post hoc test $(\alpha=0.05)$ was applied to detect differences between means. Data are shown in the figures as shell water $\mathrm{pO}_{2}$ frequency distributions during water and air exposure, calculated from the original data using Excel.

Tissue pH (pHi). Tissue $\mathrm{pH}$ was determined in both years in gill tissue of limpets from both subpopulations, using the homogenate technique (Pörtner et al. 1990). The system was thermostated to $4^{\circ} \mathrm{C}$, the lowest operable temperature, and the $\mathrm{pH}$ electrode (SenTix Mic, WTW) was calibrated with precise calibration solutions (AppliChem; pH 6.865-A1259; pH 7.413-A1260). Readings of $\mathrm{pH}$ were recorded on a Kipp \& Zonen chart recorder. Gill tissue (100 to $200 \mathrm{mg}$ ) was ground in liquid nitrogen, and the powder was added to a $0.5 \mathrm{ml}$ Eppendorf cup containing $0.15 \mathrm{ml}$ of medium composed of $160 \mathrm{mM}$ potassium fluoride and $2 \mathrm{mM}$ nitrilotriacetic acid. The cup was closed after layering with air-bubble-free medium, and the tissue was homogenised by ultrasound (Brandson sonifier 450, duty cycle $40 \%$, output control 8) at $0^{\circ} \mathrm{C}$ and centrifuged at $20000 \times g$ at $4^{\circ} \mathrm{C}$ for $30 \mathrm{~s}$.

Organic acids modified after Eertman et al. (1996). The foot tissue was ground in liquid nitrogen and homogenised in the 3 -fold volume (w:v) of $7 \%$ perchloric acid (PCA). After centrifugation (25 min, $25000 \times g$, $4^{\circ} \mathrm{C}$ for all 3 centrifugation steps), the $\mathrm{pH}$ in the supernatant was adjusted to $\mathrm{pH} 2-3$, with $3 \mathrm{M} \mathrm{NaOH}$. Samples were centrifuged again, and the supernatant was collected and frozen at $-20^{\circ} \mathrm{C}$ to precipitate residual $\mathrm{NaCl}$. The thawed sample was centrifuged again, and the supernatant was injected into the HPLC (highperformance liquid chromatography).

Organic acids were separated on a BioRad Aminex HPX-87H column $(300 \times 7.8 \mathrm{~mm})$ by isocratic elution with $2.25 \mathrm{mM} \mathrm{H}_{2} \mathrm{SO}_{4}$, flow rate $0.6 \mathrm{ml} \mathrm{min}^{-1}$, at $60^{\circ} \mathrm{C}$ column temperature and UV detection at $210 \mathrm{~nm}$. Standards were succinate (S2378; Sigma), D(-)lactate (L1000; Sigma), fumarate (F1506; Sigma), acetate (24,285-3; Aldrich) and propionate (P1880; Sigma).

ATP/ADP/AMP. Adenylate concentrations were measured after Lazzarino et al. (2003) using HPLC. Frozen foot tissue was ground in liquid nitrogen and homogenised with a micropistill in a $1.5 \mathrm{ml}$ reaction vial with ice-cold, nitrogen-saturated precipitation

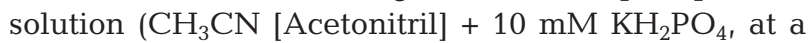

ratio of $3: 1, \mathrm{pH} 7.4)$ at a $1: 10(\mathrm{w}: \mathrm{v})$ tissue to medium ratio. The precipitation solution was prepared weekly, and the $\mathrm{pH}$ was checked daily. The homogenate was centrifuged at $20690 \times g$ for $10 \mathrm{~min}$ at $4^{\circ} \mathrm{C}$, and the clear supernatants were stored on ice. Pellets were supplemented with $1 \mathrm{ml}$ of the precipitation solution and resuspended for several seconds using an ultraturrax, centrifuged again as above, and the supernatants combined. This extract was washed with the double volume of chloroform (10 s vortexed with HPLC grade $\mathrm{CH}_{3} \mathrm{Cl}$ ) and centrifuged as above. The upper aqueous phase, containing the water-soluble low molecular weight compounds, was collected and washed again twice with chloroform. Supernatants were then stored at $-80^{\circ} \mathrm{C}$ until measurement.

Samples were separated by HPLC using a Kromasil $250 \times 4.6 \mathrm{~mm}, 5 \mu \mathrm{m}$ particle size column (Eka Chemicals, AB) and its own guard column. The injection volume was $50 \mu \mathrm{l}$ of undiluted extract. HPLC conditions (solvents, gradient, flow rate, detection) were applied as described in Lazzarino et al. (2003). AMP, ADP and ATP standards were purchased from Sigma. Adenylate concentrations in the samples were calculated using Karat Software 7.0. Energy charge (EC) after Atkinson (1968) (cf. Ataullakhanov \& Vitvitsky 2002):

$$
\mathrm{EC}=[\mathrm{ATP}+(\mathrm{ADP} / 2)] /(\mathrm{ATP}+\mathrm{ADP}+\mathrm{AMP})
$$

The total amount of adenylates was calculated after Ataullakhanov \& Vitvitsky (2002):

$$
\text { Total adenylate }=\text { ATP }+ \text { ADP }+ \text { AMP }
$$

Citrate synthase activity. The enzyme activity of the mitochondrial marker citrate synthase (CS: EC 4.1.3.7, key enzyme of the citric acid cycle) was measured in foot tissue of intertidal and subtidal control specimens following Sidell et al. (1987). Extraction was carried out as described by Abele et al. (2008).

As statistical analyses, influence of the factors time of air exposure and subpopulation on the biochemical parameters was analysed using multiple regression with the Tukey post hoc test $(\alpha=0.05)$ to detect differences between group means. A Gaussian distribution of the data was tested using the Kolmogorov-Smirnov test (GraphPad InStat 3).

\section{RESULTS}

\section{Differences in shell morphology between intertidal and subtidal Nacella concinna}

Mean length, width, height and weight of intertidal limpets were significantly smaller than those of the subtidal limpets (Table 1). The calculated parameters shell volume, circumference, steepness and roundness 
Table 1. Nacella concinna. Shell morphometrics of intertidal $(n=181)$ and subtidal $(n=136)$ limpets from Potter Cove, King George Island, South Shetlands. All values are means \pm SD

\begin{tabular}{|c|c|c|c|c|c|c|c|c|}
\hline & $\begin{array}{l}\text { Length } \\
(\mathrm{mm})\end{array}$ & $\begin{array}{l}\text { Width } \\
(\mathrm{mm})\end{array}$ & $\begin{array}{l}\text { Height } \\
(\mathrm{mm})\end{array}$ & $\begin{array}{l}\text { Weight } \\
\text { (g) }\end{array}$ & $\begin{array}{l}\text { Volume } \\
\left(\mathrm{mm}^{3}\right)\end{array}$ & $\begin{array}{l}\text { Circumference } \\
(\mathrm{mm})\end{array}$ & Steepness & Roundness \\
\hline Intertidal & $32.1 \pm 2.66$ & $23.18 \pm 2.03$ & $12.04 \pm 1.63$ & $1.58 \pm 0.52$ & $2467 \pm 691$ & $89.6 \pm 7.32$ & $0.43 \pm 0.04$ & $0.70 \pm 0.02$ \\
\hline Subtidal & $43.17 \pm 6.16$ & $29.85 \pm 4.53$ & $12.89 \pm 2.99$ & $1.79 \pm 0.83$ & $4680 \pm 2210$ & $116.6 \pm 16.9$ & $0.35 \pm 0.05$ & $0.69 \pm 0.03$ \\
\hline$t$-test & $\mathrm{p}<0.0001$ & $\mathrm{p}<0.0001$ & $\mathrm{p}=0.0013$ & $\mathrm{p}=0.008$ & $\mathrm{p}<0.0001$ & $\mathrm{p}<0.0001$ & $p<0.0001$ & $p<0.0001$ \\
\hline
\end{tabular}

also differed significantly between intertidal and subtidal shells (Table 1). Fig. 1A indicates intertidal shells to be steeper than subtidal shells, with a higher volume to circumference relationship in intertidal limpets (ANCOVA, $F=2821.42, \mathrm{p}<0.001, \mathrm{n}=314$ ). Fig. 1B indicates subtidal limpets to have larger inner shell volumes than intertidal specimens of the same wet mass (ANCOVA, $F=68.298, \mathrm{p}=0.0001, \mathrm{n}=72$ ). The amount of shell water was calculated by subtracting shell weight and individual SFWM from the weight of the intact/live individual. Statistical analysis confirmed that subtidal limpets have significantly more shell water (subtidal $2.16 \pm 1.4 \mathrm{~g}$ of shell water, $\mathrm{n}=28$; intertidal $0.76 \pm 0.8 \mathrm{~g}, \mathrm{n}=45$; Kruskal-Wallis, $\mathrm{p}<0.001$ ) than intertidal limpets. However, SFWM was also higher in the subtidal limpets so that the ratio of shell water to SFWM remained the same in both subpopulations.

\section{Water loss in air-exposed Nacella concinna: differences between subpopulation and dependence on body mass}

Fig. 2 shows the time course of the percent water loss in intertidal and subtidal limpets exposed to air at $0^{\circ} \mathrm{C}$ recorded in 2007 . The percent water loss in intertidal limpets was lower than that in subtidal specimens, but increased significantly over time in air-exposed individuals (ANCOVA, $F=5.96, \mathrm{p}=0.0051, \mathrm{n}=47$ ). On the contrary, in subtidal limpets the percentage of water loss was higher from the beginning of the air exposure on and remained constant over the full $24 \mathrm{~h}$ (ANCOVA, $F=2.52, \mathrm{p}=0.10, \mathrm{n}=28$ ).

ANCOVA indicated significant effects of subpopulation (inter- vs. subtidal), exposure time and body mass on water loss (percentage data were arcsine transformed), as well as a significant interaction between the parameters subpopulation and body mass (Table 2). Subsequent separate ANCOVAs for both subpopulations revealed distinct differences of the effect of SFWM in intertidal and subtidal limpets. In the intertidal subpopulation, larger individuals lost more water than smaller snails. On the contrary, in the subtidal subpopulation, the larger individuals appeared less susceptible to desiccation and lost comparably less water than smaller individuals (negative correlation between water loss and body mass are shown in the model in Table 2).
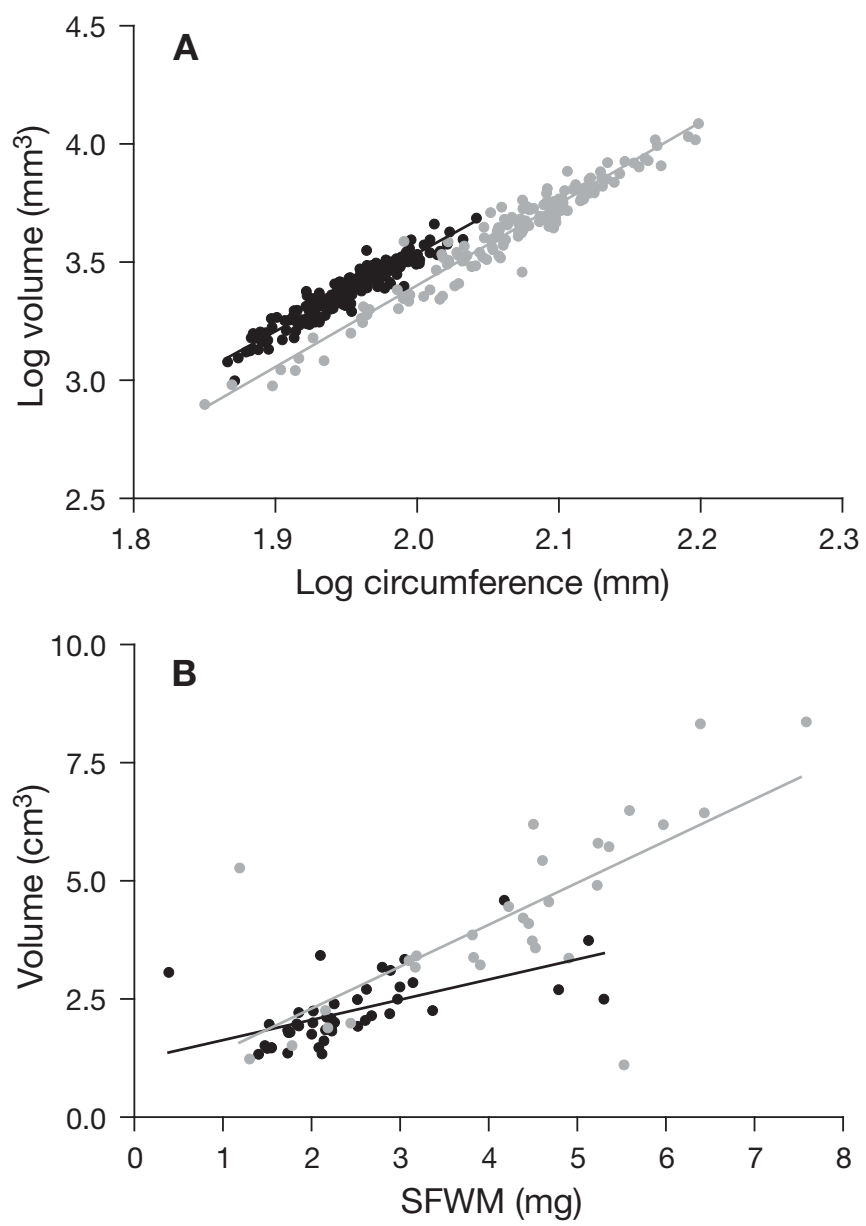

Fig. 1. Nacella concinna. Inner shell volume plotted against (A) circumference and (B) shell-free wet mass (SFWM) for the intertidal $(\bullet)$ and subtidal $(\bullet)$ limpets from Potter Cove, King George Island, South Shetlands. (A) Intertidal: $\log$ (volume) = $3.3 \log$ (circumference) $-3.139, \mathrm{r}^{2}=0.9035, \mathrm{n}=136$; subtidal: $\log$ (volume) $=3.46 \log$ (circumference) $-3.508, \mathrm{r}^{2}=0.9436$, $\mathrm{n}=136$. (B) Intertidal: volume $=0.427 \mathrm{SFWM}+1.206, \mathrm{r}^{2}=$ $0.346, \mathrm{p}<0.05, \mathrm{n}=45$; subtidal: volume $=0.887 \mathrm{SFWM}+$ $0.527, \mathrm{r}^{2}=0.529, \mathrm{p}<0.05, \mathrm{n}=30$. Volume-wet mass relationship differed between subpopulations (ANCOVA, $p=0.0125$ ) 


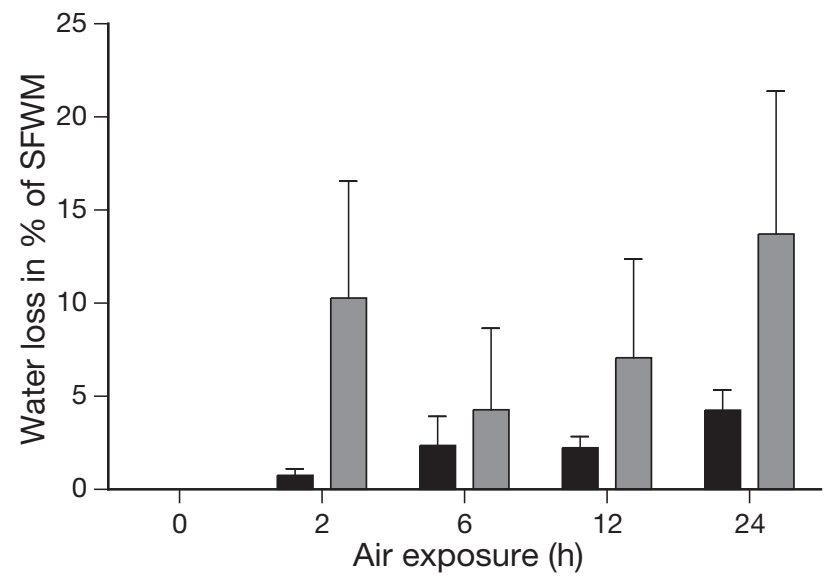

Fig. 2. Nacella concinna. Water loss in percent of whole individual shell-free wet mass (SFWM) during air exposure in intertidal (black bars) and subtidal (grey bars) limpets. Mean + $\mathrm{SD}, \mathrm{n}=6$ to 10 limpets per group

\section{Gill tissue pH in intertidal and subtidal limpets during air exposure}

Tissue pH was analysed in gills of subtidal and intertidal control specimens in 2005 and 2007. After confirming that $\mathrm{pH}$ did not differ significantly between years (ANOVA, p > 0.05), values were pooled and analysed for general differences between subpopulations. Intertidal Nacella concinna gill pH (7.391 \pm $0.064, \mathrm{n}=10$ ) was significantly more acidic $(\mathrm{p}=0.0019)$ than subtidal gill $\mathrm{pH}(7.707 \pm 0.188, \mathrm{n}=8)$ under submersed control conditions.

Table 2. Nacella concinna. Full factorial ANCOVA interaction model of effects of subpopulation (subtidal, intertidal), air exposure time (h) and individual shell-free wet mass (SFWM) on water loss (percentage data, arcsine transformed) in limpets from King George Island. Full interaction model: $F=5.9283$, $\mathrm{p}=0.0004, \mathrm{n}=75$. The effect of body mass was tested in 2 separate models for both subpopulations -intertidal: $F=5.9587$,

$\mathrm{p}=0.0051, \mathrm{n}=47 ;$ subtidal $F=2.5188, \mathrm{p}=0.1008, \mathrm{n}=28$

\begin{tabular}{|lcrc|}
\hline & Estimate & $t$-ratio & $\mathrm{p}$ \\
\hline Full interaction model: & & & \\
Intercept & 20.437 & 8.15 & $<0.0001$ \\
Subpopulation & -2.12 & -2.14 & 0.0362 \\
Exposure time & 0.205 & 2.10 & 0.0393 \\
SFWM & 0.7467 & 1.25 & 0.2160 \\
SFWM $\times$ Subpopulation & 1.585 & 2.65 & 0.0099 \\
Exposure time $\times$ Subpopulation & 0.1381 & 1.40 & 0.1673 \\
Intertidal limpets: & & & \\
Intercept & 13.55193 & 4.19 & 0.0001 \\
Exposure time & 0.30535 & 2.75 & 0.0086 \\
SFWM & 2.0017 & 2.08 & 0.0435 \\
Subtidal limpets: & & & \\
Intercept & 24.7129 & 6.13 & $<0.0001$ \\
Exposure time & 0.0407 & 0.24 & 0.8152 \\
SFWM & -1.20024 & -2.19 & 0.0378 \\
\hline
\end{tabular}

Fig. 3 shows changes in pHi in the gill tissue from the 2007 air exposure experiment. The gill pHi rose significantly within the first $6 \mathrm{~h}$ of air exposure in intertidal limpets and was back to the control level in 12 and $24 \mathrm{~h}$ air-exposed snails (ANOVA and Tukey, $\mathrm{p}<$ 0.05). The pHi in subtidal limpet gills (Fig. 3) decreased slightly during air exposure from 7.7 to 7.5 , but the change did not reach significance $(p>0.05)$.

\section{Adjustment of shell water $\mathrm{pO}_{2}$ in submersed and air-exposed limpets from both shore levels}

$\mathrm{pO}_{2}$ measurements were carried out in 2007 only. Although the experimental snails were submersed in fully oxygenated seawater and exposed to air on emersion, $\mathrm{pO}_{2}$ in the shell never reached $>15 \mathrm{kPa}(70 \%$ air saturation) in either subpopulation. $\mathrm{pO}_{2}$ frequency distribution under water was more variable (Fig. 4A) than during air exposure (Fig. 4B) in both subpopulations. Especially intertidal limpets under water had very variable $\mathrm{pO}_{2}$ in their shell tip, with values ranging between 0 and $13 \mathrm{kPa}$. In subtidal limpets, $75 \%$ of all $\mathrm{pO}_{2}$ values recorded for $5 \mathrm{~min}$ measuring intervals under water were between 0 and $1 \mathrm{kPa}$, and the highest recorded $\mathrm{pO}_{2}$ was $12 \mathrm{kPa}$. During air exposure the overall $\mathrm{pO}_{2}$ range in both limpet subpopulations was significantly narrowed to between 0 and $3 \mathrm{kPa}$ in intertidal (Fig. 4A) and 0 to $4 \mathrm{kPa}$ in subtidal limpets (Fig. 4B); $90 \%$ of intertidal and $85 \%$ of subtidal limpet $\mathrm{pO}_{2}$ data were between 0 and $0.5 \mathrm{kPa}$, indicating that the inner shell space becomes hypoxic in both groups during air exposure.

The full factorial interaction model with the parameters exposure (air vs. water), shore level (intertidal vs. subtidal) and exposure time indicated that all parameters have significant effects on limpet shell water $\mathrm{pO}_{2}$. Moreover, cross effects were visible for the interaction between shore level and exposure, exposure and expo-

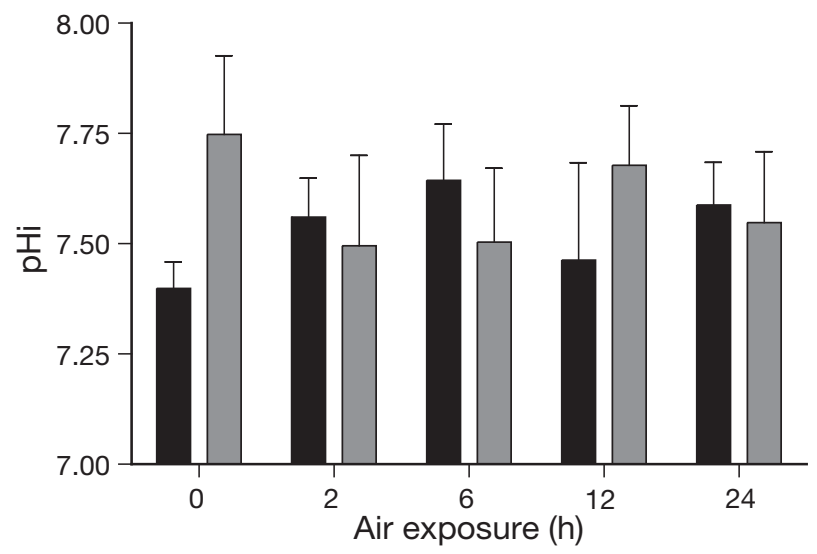

Fig. 3. Nacella concinna. Gill tissue $\mathrm{pH}(\mathrm{pHi})$ of intertidal (black bars) and subtidal (grey bars) limpets during air exposure in 2007. Mean $+\mathrm{SD}, \mathrm{n}=5$ to 7 limpets per group 


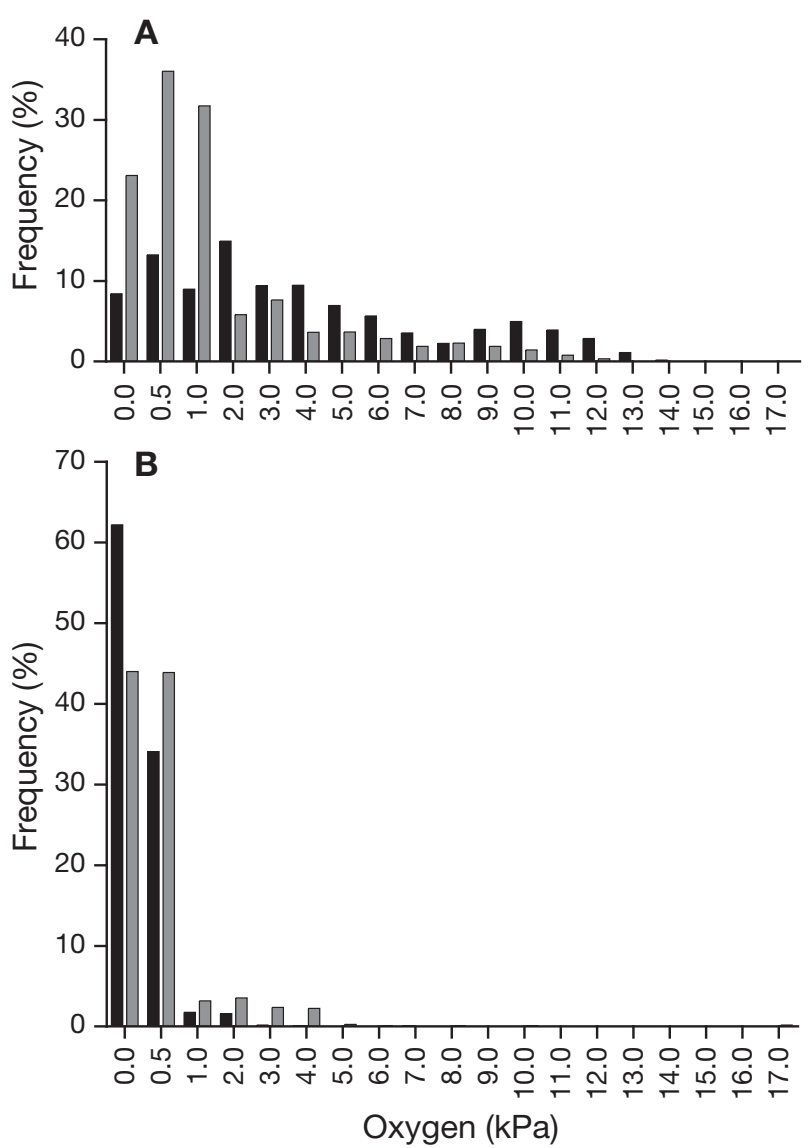

Fig. 4. Nacella concinna. Mean $\mathrm{pO}_{2}$ frequency of 5 min measuring intervals in the shell water of intertidal (black bars, $\mathrm{n}=9$ ) and subtidal (grey bars, $\mathrm{n}=5$ ) limpets (A) under water and (B) during experimental air exposure

sure time, and shore level and exposure time (Table 3). Hence, inter- and subtidal limpets differ significantly in the adjustment of shell water $\mathrm{pO}_{2}$ during experimental air exposure and submergence; moreover, the changes in shell water $\mathrm{pO}_{2}$ differed in both subpopulations over the time of air exposure. The Tukey honestly significant difference (HSD) test performed with Box-Coxtransformed data for the 4 groups of inter- and subtidal limpets, each submerged and during aerial exposure, indicated each group to be significantly different from all others with $\mathrm{p}<0.05$ (Table 4 ). The alphabetical order of the letters in Table 4 indicates the distance from the value of the 'intertidal water' group. Hence, the statistical analysis of the $\mathrm{pO}_{2}$ data confirmed the impression from the frequency distribution graphs (Fig. 4): intertidal and subtidal limpets differ significantly with respect to the change of shell water oxygenation during air exposure, as well as when submerged under water. Whereas the $\mathrm{pO}_{2}$ in intertidal limpet shell water changes significantly upon air exposure, no such clear response could be distinguished in the 'reaction' of subtidal specimens during experimental emersion.
Table 3. Nacella concinna. Factor impact estimates obtained from the full factorial interaction model for the effects of the factors subpopulation (intertidal vs. subtidal), exposure (air vs. submerged in water) and time on the $\mathrm{pO}_{2}$ in the extrapallial water of the shell top of the limpet $N$. concinna. All factors and interactions had significant effects with $\mathrm{p}($ prob $>t)<0.001$

\begin{tabular}{|lc|}
\hline Term & Estimate \\
\hline Exposure (air) & -0.198945 \\
Subpopulation (intertidal) & -0.08611 \\
Exposure time & 0.0006065 \\
Subpopulation (intertidal) $\times$ Exposure (air) & -0.374168 \\
Exposure (air) $\times$ Exposure time & 0.0005211 \\
Shore level (intertidal) $\times$ Exposure time & -0.000175 \\
\hline
\end{tabular}

Table 4. Nacella concinna. Differences between shell water $\mathrm{pO}_{2}$ in intertidal and subtidal limpet under water and during air exposure. Analysis of Box-Cox-transformed data in different groups with Tukey post hoc. Different letters indicate significant differences $(\mathrm{p}<0.05)$ between $\mathrm{pO}_{2}$ levels recorded in different groups during the entire time of air exposure (air) or submergence (water). The alphabetical order of the group indicates the distance of each group from the intertidal water group

\begin{tabular}{|lllc|}
\hline Level & $\begin{array}{c}\mathrm{pO}_{2} \text { means } \\
(\mathrm{kPa})\end{array}$ & Estimate & $\begin{array}{c}\text { Grouping } \\
\text { with } 0\end{array}$ \\
\hline Intertidal, water & 2.577 & 1.4837245 & $\mathrm{~A}$ \\
Intertidal, air & 0.0933 & 0.3374979 & $\mathrm{D}$ \\
Subtidal, water & 1.339 & 0.9076090 & $\mathrm{C}$ \\
Subtidal, air & 1.482 & 1.2580552 & $\mathrm{~B}$ \\
\hline
\end{tabular}

\section{Onset of anaerobic metabolism in intertidal and subtidal limpets during air exposure}

Fig. 5 shows changes in organic acids, intermediates of anaerobic metabolism in hypoxia-tolerant marine invertebrates (Tielens et al. 2002) in foot tissue of intertidal and subtidal limpets during up to $24 \mathrm{~h}$ of air exposure (data from 2005). ANCOVA detected significant differences in the concentrations of lactate $(F=10.48$, $\mathrm{p}<0.001, \mathrm{n}=53$ ), propionate (effect of subpopulation only, $F=4.25, \mathrm{p}=0.014, \mathrm{n}=53$ ) over time and between subpopulations, with higher concentrations in subtidal than intertidal limpets. After $12 \mathrm{~h}$ of air exposure, acetate, lactate and succinate levels were significantly increased over non-air-exposed controls (Tukey HSD) in subtidal specimens. Propionate values increased 5 -fold only after $24 \mathrm{~h}$ of air exposure in subtidal limpets, but the increase did not reach significance due to the high inter-individual variability. The only anaerobic metabolite that increased to the same extent in air-exposed limpets from both subpopulations was acetate (ANCOVA, $F=10.12, \mathrm{p}=0.001, \mathrm{n}=55$ for all data; subtidal only $p=0.0014$; Fig. $5 \mathrm{~A}$ ). The acetate concentration seems even higher in intertidal than in 

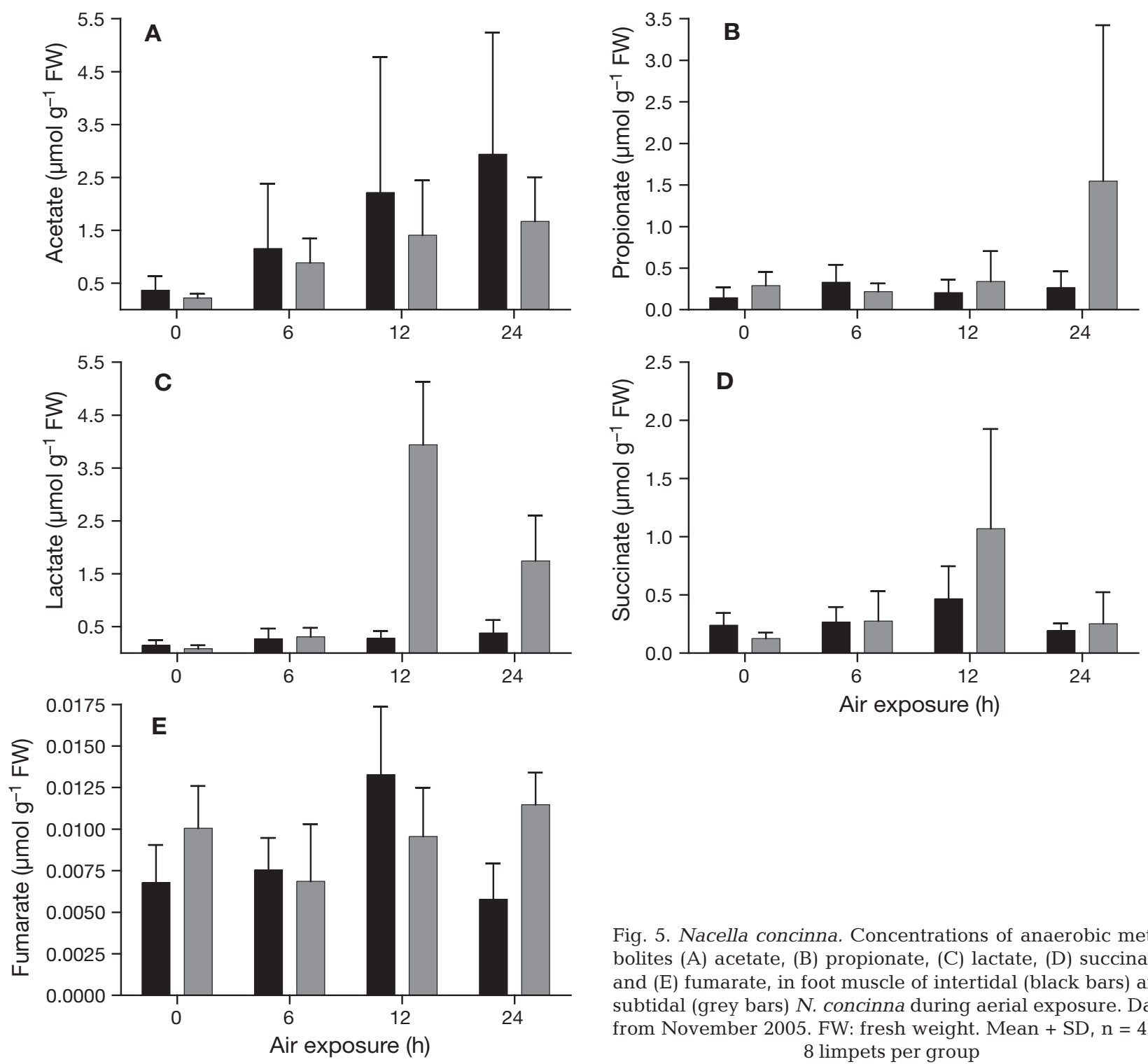

Fig. 5. Nacella concinna. Concentrations of anaerobic metabolites (A) acetate, (B) propionate, (C) lactate, (D) succinate, and (E) fumarate, in foot muscle of intertidal (black bars) and subtidal (grey bars) $N$. concinna during aerial exposure. Data from November 2005. FW: fresh weight. Mean $+\mathrm{SD}, \mathrm{n}=4$ to 8 limpets per group

subtidal limpets, but statistically there was no difference between subpopulations $(p=0.8)$.

\section{Adenylate concentrations and CS activity in intertidal and subtidal limpets during air exposure}

Intertidal limpets had higher overall adenylate concentrations (ATP + ADP + AMP) in foot tissue than subtidal snails ( $F=25.34, \mathrm{p}<0.0001, \mathrm{n}=60$; Table 5$)$, mainly due to higher ATP concentration $(F=28.1$, p $<0.0001$, $\mathrm{n}=60$ ) in control and air-exposed individuals. If only submerged control specimens were considered, the difference between subpopulations was still significant with $\mathrm{p}<0.05$. The amount of ADP was also higher in intertidal than subtidal limpets, although the difference was less clear $(F=5.23, \mathrm{p}=0.0356, \mathrm{n}=60)$, whereas AMP

concentrations were similar in both subpopulations $(F=0.27, \mathrm{p}=0.602, \mathrm{n}=60)$. EC increased in both subpopulations over the time course of air exposure (intertidal: $F=4.8, \mathrm{p}=0.046, \mathrm{n}=29$; subtidal: $F=8.07, \mathrm{p}=0.008$, $\mathrm{n}=31$; Table 5). Total adenylate concentration increased in both subpopulations during air exposure (ANCOVA, $\mathrm{p}=0.0242$ ), with a major increase after $12 \mathrm{~h}$.

$\mathrm{CS}$ activity was $1.2 \pm 0.16 \mathrm{U} \mathrm{g}^{-1}$ wet mass $(0.013 \pm$ $0.002 \mathrm{U} \mathrm{mg}^{-1}$ protein) in intertidal $(\mathrm{n}=7)$ and $1.4 \pm 0.33 \mathrm{U}$ $\mathrm{g}^{-1}$ wet mass $\left(0.016 \pm 0.003 \mathrm{U} \mathrm{mg}^{-1}\right.$ protein $)$ in subtidal $(n=7)$ control limpet foot muscle, with no significant difference between subpopulations $(p=0.13)$. Only a small number of snails yielded sufficient foot tissue to determine the individual ATP:CS ratio, which was significantly higher in the intertidal specimens (intertidal: $0.4 \pm$ $0.1 \mu \mathrm{mol}$ ATP $\mathrm{U}^{-1} \mathrm{CS}, \mathrm{n}=3$; subtidal: $0.16 \pm 0.06 \mu \mathrm{mol}$ ATP $\mathrm{U}^{-1} \mathrm{CS}, \mathrm{n}=6$; Mann-Whitney test $\mathrm{p}=0.024$ ). 
Table 5. Nacella concinna. Adenylate concentrations in the foot muscle of limpets during air exposure; p-values indicate the

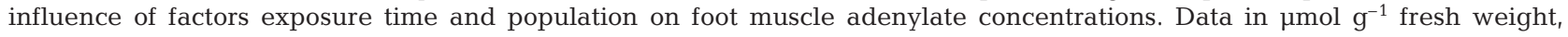
mean $\pm S D, n=6$. EC: energy charge

\begin{tabular}{|c|c|c|c|c|c|c|}
\hline & ATP & $\mathrm{ADP}$ & AMP & $\mathrm{EC}$ & $\mathrm{ATP}+\mathrm{ADP}+\mathrm{AMP}$ & AMP/ATP \\
\hline \multicolumn{7}{|l|}{ Intertidal } \\
\hline $0 \mathrm{~h}$ & $0.351 \pm 0.12$ & $0.067 \pm 0.02$ & $0.016 \pm 0.01$ & $0.879 \pm 0.05$ & $0.443 \pm 0.13$ & $0.038 \pm 0.02$ \\
\hline $2 \mathrm{~h}$ & $0.405 \pm 0.05$ & $0.072 \pm 0.02$ & $0.012 \pm 0.01$ & $0.9 \pm 0.03$ & $0.491 \pm 0.04$ & $0.036 \pm 0.03$ \\
\hline $6 \mathrm{~h}$ & $0.384 \pm 0.06$ & $0.076 \pm 0.03$ & $0.022 \pm 0.01$ & $0.876 \pm 0.04$ & $0.482 \pm 0.08$ & $0.059 \pm 0.03$ \\
\hline $12 \mathrm{~h}$ & $0.453 \pm 0.10$ & $0.07 \pm 0.015$ & $0.01 \pm 0.005$ & $0.915 \pm 0.015$ & $0.534 \pm 0.12$ & $0.022 \pm 0.01$ \\
\hline $24 \mathrm{~h}$ & $0.44 \pm 0.10$ & $0.069 \pm 0.03$ & $0.013 \pm 0.01$ & $0.909 \pm 0.036$ & $0.523 \pm 0.12$ & $0.032 \pm 0.03$ \\
\hline Time & $p=0.321$ & $p=0.291$ & $p=0.186$ & $p=0.046$ & $p=0.615$ & $p=0.109$ \\
\hline $\mathrm{n}=29$ & $F=0.846$ & $F=1.458$ & $F=2.2$ & $F=4.8$ & $F=0.159$ & $F=3.107$ \\
\hline \multicolumn{7}{|l|}{ Subtidal } \\
\hline $0 \mathrm{~h}$ & $0.22 \pm 0.08$ & $0.052 \pm 0.01$ & $0.014 \pm 0.007$ & $0.846 \pm 0.06$ & $0.286 \pm 0.08$ & $0.084 \pm 0.076$ \\
\hline $2 \mathrm{~h}$ & $0.269 \pm 0.048$ & $0.055 \pm 0.01$ & $0.015 \pm 0.01$ & $0.876 \pm 0.04$ & $0.338 \pm 0.05$ & $0.060 \pm 0.05$ \\
\hline $6 \mathrm{~h}$ & $0.245 \pm 0.08$ & $0.06 \pm 0.016$ & $0.024 \pm 0.026$ & $0.838 \pm 0.06$ & $0.329 \pm 0.11$ & $0.09 \pm 0.1$ \\
\hline $12 \mathrm{~h}$ & $0.294 \pm 0.11$ & $0.066 \pm 0.02$ & $0.016 \pm 0.01$ & $0.862 \pm 0.045$ & $0.376 \pm 0.12$ & $0.065 \pm 0.04$ \\
\hline $24 \mathrm{~h}$ & $0.346 \pm 0.096$ & $0.058 \pm 0.018$ & $0.011 \pm 0.005$ & $0.905 \pm 0.02$ & $0.414 \pm 0.11$ & $0.030 \pm 0.01$ \\
\hline Time & $p=0.016$ & $p=0.997$ & $p=0.263$ & $p=0.008$ & $p=0.052$ & $p=0.044$ \\
\hline $\mathrm{n}=31$ & $F=6.603$ & $F=1.14 \mathrm{e}^{-5}$ & $F=1.304$ & $F=8.075$ & $F=4.103$ & $F=4.423$ \\
\hline Population & $\mathrm{p}<0.001$ & $p=0.026$ & $p=0.602$ & $p=0.006$ & $\mathrm{p}<0.0001$ & $p=0.028$ \\
\hline $\mathrm{n}=60$ & $F=28.103$ & $F=5.234$ & $F=0.275$ & $F=8.119$ & $F=25.341$ & $F=5.1053$ \\
\hline
\end{tabular}

\section{DISCUSSION}

In the Antarctic, intertidal limpets Nacella concinna are, on the one hand, confronted with extreme environmental hazards, whereas, on the other hand, they can exploit the microalgal biofilm and macroalgal propagules (Zacher et al. 2007) that support high densities of consumers in spring and summer. The average subpopulation density at King George Island is 32 ind. $\mathrm{m}^{-2}$, with maximum densities of $>400$ ind. $\mathrm{m}^{-2}$ (Silva et al. 1999). Split into 2 morphologically distinguishable subpopulations, exploiting food resources on different shore levels, presents an advantage for the productivity of herbivorous grazers; Wolcott (1973) described this strategy as the 'expansionist exploitation theory'. However, the conundrum remains that obviously only one part of the subpopulation can make it to the higher shore and survive there.

\section{Different response to air exposure in subtidal and intertidal Antarctic limpets}

The primary aim of our work was to understand the behavioural strategies and biochemical patterns that distinguish migratory intertidal from stationary subtidal limpet morphotypes, their behavioural differences and their metabolic adaptation to life on different shore levels. This paper focuses on the capacity to balance water loss and to regulate the shell water $\mathrm{pO}_{2}, 2$ features under behavioural control of the individuals (Truchot 1990, see Massabuau 2001 for $\mathrm{pO}_{2}$ balance). We found some clear-cut differences between the intertidal and subtidal Nacella concinna morphotypes, which are summarized for overview in Table 6. First, intertidal limpets have a smaller shell circumference than subtidal limpets of identical shell volume. This minimizes the contact zone over which water can evaporate during air exposure on tidal emersion. Under in situ conditions Antarctic limpets avoid prolonged air exposure. Fewer individuals crawl upwards and most limpets stay in moist cracks and crevices or at the bottom of the rocks (authors' pers. obs.). The maximum emersion time of intertidal limpets was between 4 and $6 \mathrm{~h}$. Bigger intertidal specimens were less able to control water loss, possibly due to their longer shell circumference and the higher amount of water in their shell (higher volume to wet mass ratio). The inverse effect of size on water loss in subtidal and intertidal limpets highlights the physiological differentiation between both subpopulations. Higher offset of water loss in all subtidal specimens underlines their generally reduced capability to avoid desiccation once exposed to air and is in line with lower contractive power in general as reported earlier by Davenport (1988), who stated that subtidal individuals contract less tightly to the rocks and are easier removed during collection by divers. Subtidal limpets have more shell water and possibly lose most of it in an early phase of aerial exposure, before contracting their shells and becoming hypoxic in an attempt to avoid further desiccation.

The second behaviourally regulated parameter we analysed was the $\mathrm{pO}_{2}$ in the extrapallial water in the top of the shell. Capability to regulate tissue and body water oxygenation and $\mathrm{pHi}$ in response to changeable environmental conditions in macro-invertebrates is an important prerequisite to stabilize metabolic home- 
Table 6. Nacella concinna. Summary of morphological differences and parameter changes in subtidal and intertidal limpets during aerial exposure. Arrows indicate direction of change during aerial exposure; $\rightarrow$ : no change

\begin{tabular}{|c|c|c|}
\hline Trait & Subtidal & Intertidal \\
\hline \multicolumn{3}{|l|}{ Morphology } \\
\hline Height & Short & Tall \\
\hline Circumference to volume ratio & High & Low \\
\hline Volume to wet mass ratio & High & Low \\
\hline \multicolumn{3}{|l|}{ Change during air exposure } \\
\hline Water loss & High $\uparrow$ & Low $\rightarrow$ \\
\hline Effect of size on water loss & $\begin{array}{c}\text { Large sizes } \\
\text { less }\end{array}$ & $\begin{array}{c}\text { Large sizes } \\
\text { more }\end{array}$ \\
\hline Shell water $\mathrm{pO}_{2}$ & $\uparrow$ & $\downarrow$ \\
\hline Organic acids & $\uparrow$ & $\downarrow$ \\
\hline Tissue $\mathrm{pH}$ & $\rightarrow$ & $\uparrow$ \\
\hline Adenylates & High & Less \\
\hline Adenylates $\times$ time & $\uparrow$ & $\uparrow$ \\
\hline
\end{tabular}

ostasis and survive extreme and rapidly occurring environmental change. The water in the shell top is representative of the level of oxygenation the limpets maintain next to their tissues, often against variable oxygen levels in the outside medium (Massabuau 2003). It is not necessarily a reflection of an individual's oxygen uptake, but rather of its ventilation activity. However, shell water is also the last oxygen reserve under hypoxic conditions, and a decrease in shell water oxygenation indicates that oxygen is consumed by the limpet without ventilatory compensation.

Our measurements of shell water $\mathrm{pO}_{2}$ indicate more active ventilation of the inner shell space in intertidal than subtidal limpets under water. $\mathrm{pO}_{2}$ values between 2 and $13 \mathrm{kPa}$ were recorded with much higher frequency than in sublittoral specimens, where $\mathrm{pO}_{2}$ was mainly between 0 and $1 \mathrm{kPa}$ even in a fully oxygenated environment. Better ventilation of the inner shell volume is presumably indicative of higher oxygen demand of intertidal limpets compared to non-migratory subtidal specimens under water, but so far nobody has investigated the difference. We observed intertidal limpets in our aquaria to be more active crawlers than their subtidal conspecifics; moreover, their higher ATP:CS ratio speaks for more active aerobic metabolism in intertidal limpet foot muscle during routine activity.

During experimental emersion the picture changed completely. Shell ventilation was stopped altogether in intertidal specimens, and $>90 \%$ of all measurements were $<1 \mathrm{kPa}$. Together, low $\mathrm{pO}_{2}$ in the shell top, absence of lactate accumulation, as well as stable ATP levels and energy charge in the foot muscle of airexposed intertidal Nacella concinna indicate that the limpets switch to breathing air during low tides. This is a characteristic behaviour for high intertidal molluscs, including several species of patellids from temperate waters (for review see McMahon 1988). These animals perform short uplifting movements (limpets) or openings of the shells (cockles), so-called gaping behaviour, in an attempt to maintain an aerobic metabolism and avoid desiccation over several hours without water (Truchot 1990). A 3-fold increase in the mean acetate concentration observed in foot tissue, caused by elevated acetate levels in 3 out of 6 intertidal $N$. concinna in the $24 \mathrm{~h}$ exposure group, is not huge. Brinkhoff et al. (1983) exposed the common limpet Patella vulgata to complete anoxia and found a 5-fold increase in acetate levels after 12 and $24 \mathrm{~h}$. However, it indicates that additional input from mitochondrial anaerobic energy production during prolonged air exposure is possible in Antarctic intertidal limpets. Air-exposed subtidal specimens had significantly lower foot ATP content and $\mathrm{EC}_{i}$ they were generally less tolerant of air exposure and switched to anaerobic glycolysis, which was visible in an 8-fold increase in tissue lactate levels after $12 \mathrm{~h}$ of desiccation stress. Although they clamped shells to the bottom and obviously were not able to gape air during emersion, they lost more shell water then intertidal individuals, presumably due to their lower tenacity and perhaps also due to their higher shell water content.

\section{Exposed to air in the cold: comparing the response in Antarctic limpets and temperate molluscs}

Our data represent a first analysis of energy metabolism of limpets collected from the South Shetland Islands, distinguishing inter- and subtidal limpets. The adenylate concentrations we measured are strikingly lower than those reported by Pörtner et al. (1999) for Nacella concinna foot muscle from Signey Island of the South Orkneys. The sum of ATP + ADP + AMP (Ade in Pörtner et al. 1999; Table 1) was around 5 times higher in South Orkney subtidal limpets, which were collected in summer. This may be due to prolonged maintenance under laboratory conditions ( $>6 \mathrm{mo}$ ) by Pörtner et al. (1999) rather than to a higher temperature regime at the lower latitude sub-Antarctic South Orkney sampling site. In contrast, the anaerobic capacity of the limpets, sampled in situ at King George Island, was higher than in the South Orkneys study and more comparable to values for temperate intertidal bivalves and patellides (Brinkhoff et al. 1983, Nicchitta \& Ellington 1983).

Nicchitta \& Ellington (1983) investigated adenylate energy charge and metabolite levels in intertidal (Geukensia demissa) and subtidal (Modiolus squamosus) bivalves over $12 \mathrm{~h}$ of aerial exposure and $12 \mathrm{~h}$ of subsequent recovery. The adenylate EC in both individuals was congruent with the values in the Antarctic 
limpets, remained stable throughout air exposure in the intertidal G. demissa, and was significantly lower during air exposure of $M$. squamosus (adductor muscle in all 3 individuals). In contrast, Nacella concinna EC values and even the ATP concentrations (only of the subtidal individuals) increased significantly in both intertidal and subtidal limpets during air exposure, indicating that Antarctic snails are able to respire air (intertidal) or induce anaerobic fermentation and reduce ATP consumption (subtidal) to maintain EC when emersed. Moreover, this is in keeping with the observations of Brinkhoff et al. (1983) for $6 \mathrm{~h}$ in situ air exposure of the limpet Patella vulgata in Roscoff, Britanny, France. The authors attributed the maintenance of EC and the increase in ATP levels in foot muscle to metabolic rate depression (quiescence) of the limpet and to the possibility of air gaping in the cockle Cardium (Cerastoderma) edule. They found no indication for the onset of anaerobic metabolism in the common limpet $P$. vulgata, which may be due to the shorter exposure time $(6 \mathrm{~h})$ and the fact that the limpets were collected from the natural environment, whereas we exposed the Antarctic limpets to desiccation in a longer lasting laboratory experiment. It is interesting to note that also in our study only acetate fermentation was already switched on after $6 \mathrm{~h}$ air exposure in $N$. concinna, in keeping with the intertidal bivalves investigated by Brinkhoff et al. (1983), but contrasting to the common limpet $P$. vulgata, where acetate remained below the detection limit. Only after $12 \mathrm{~h}$ of air exposure, did lactate, succinate and propionate accumulate exclusively in the subtidal limpets. This is in keeping with the concept of Kluytmans et al. (1977), who found propionate fermentation commencing only after $12 \mathrm{~h}$ of hypoxia/anoxia in bivalves. The subtidal specimens were obviously and logically more stressed by our treatment than their intertidal companions, and the initiation of anaerobic energy production, and especially the accumulation of lactate, indicates higher sensitivity to air exposure than in common limpets from Brittany.

Cold temperatures (and the low light regime), as maintained in our experimental set-up, supported maintenance of energetic and tissue homeostasis in the Antarctic limpet. Sokolova \& Pörtner (2001) investigated periwinkles Littorina saxatilis from the White and North Seas, in high- and low-shore environments during $60 \mathrm{~h}$ of aerial exposure in a desiccator (dried air), but additionally warmed the periwinkles to $30^{\circ} \mathrm{C}$. This caused rapid loss of body water by up to $50 \%$, and, also in their study, snails from low-shore habitats were much more affected than high-shore periwinkles from the White Sea. The difference in water loss and in most biochemical/energetic parameters between highand low-shore snails was always more pronounced in
White Sea than in North Sea specimens, leading Sokolova \& Pörtner (2001) to conclude that habitat conditions, and consequently adaptation to different shore levels, were more pronounced in the White Sea population. Both studies have much in common, including the finding that an increased ability to maintain body water was associated with a reduced accumulation of organic metabolites in the high-shore periwinkles and in intertidal compared to subtidal Antarctic limpets in our study. Thus, body water might also be a temperature buffer and confer some cooling of the heated individual during evaporation. However, there are also important differences: high-shore periwinkles had $20 \%$ lower aerobic metabolic rates during aerial exposure than under water and the authors concluded that, in contrast to their low-shore conspecifics, they are metabolically depressed in air. In contrast, the intertidal Nacella concinna were more mobile during air exposure than the subtidal specimens and also seemed to be more active when covered by water.

We conclude that there appears to be a pronounced physiological differentiation between inter- and subtidal Nacella concinna with respect to physiological capacities and metabolic regulation, both under water and during air exposure. Even if the intertidal Antarctic limpets are physiologically sensitive to freshwater and high temperatures, they have evolved behavioural strategies that help them to survive, remain active under water, maintain body water balance and energetic homeostasis during air exposure presumably by respiring air, and, during all this, clamp their feet to the rocks on emersion in order to, as much as possible, avoid water loss and predation. In contrast, subtidal limpets, when exposed to air, appear metabolically depressed and switch to anaerobic fermentation for survival. This indicates that fundamental physiological diversification is the basis for the ability of one of the King George Island limpet subpopulations to colonize intertidal areas, and this diversification may have a genetic background (see Aranzamendi et al. 2008). If there is a trade-off for this extraordinary physiological adaptation in this stenothermal Antarctic invertebrate, it may consist of slower growth within the migrating intertidal subpopulation.

Acknowledgements. The authors thank M. Weeber for his excellent help during the experimental work in Jubany in 2007, T. Brey for help with the JMP data modelling, and S. Meyer for excellent technical assistance at the Alfred Wegener Institute. The study was funded by the DFG Antarctic programme, Grant Number DFG-Ab124/7 to D.A. We gratefully acknowledge the technical support by Argentine logistics staff during 2 summer seasons at Jubany Station. Finally, we thank 3 anonymous referees for constructive comments that helped improve the manuscript. 


\section{LITERATURE CITED}

Abele D, Strahl J, Brey T, Philipp E (2008) Imperceptible senescence-ageing in the ocean quahog Arctica islandica. Free Radic Res 42:474-480

Aranzamendi MC, Sahade R, Tatian M, Chiappero MB (2008) Genetic differentiation between morphotypes in the Antarctic limpet Nacella concinna as revealed by inter-simple sequence repeat markers. Mar Biol 154:875-885

Ataullakhanov FI, Vitvitsky VM (2002) What determines the intracellular ATP concentration. Biosci Rep 22:501-511

Atkinson DE (1968) Energy charge of the adenylate pool as a regulatory parameter. Interaction with feedback modifiers. Biochemistry 7:4030-4034

Barnett V, Lewis T (1994) Outliers in statistical data. Wiley, London

Beaumont AR, Wei JHC (1991) Morphological and genetic variation in the Antarctic limpet Nacella concinna (Strebel, 1908). J Molluscan Stud 57:443-450

Brêthes JC, Ferreyra G, de la Vega S (1994) Distribution, growth and reproduction of the limpet Nacella (Patinigera) concinna (Strebel, 1908) in relation to potential food availability, in Esperanza Bay (Antarctic Peninsula). Polar Biol 14:161-170

Brinkhoff W, Stöckmann K, Grieshaber M (1983) Natural occurrence of anaerobiosis in molluscs from intertidal habitats. Oecologia 57:151

Davenport J (1988) Tenacity of the Antarctic limpet Nacella concinna. J Molluscan Stud 54:355-356

Davenport J (1997) Comparison of the biology of the intertidal Subantarctic limpets Nacella concinna and Kerguelenella lateralis. J Molluscan Stud 63:39-48

Davenport J (2001) Meltwater effects on intertidal Antarctic limpets. J Mar Biol Assoc UK 81:643-649

Eertman RHM, Zurburg W, Schipper CA, Sandee B, Smaal AC (1996) Effects of PCB 126 and cadmium on the anaerobic metabolism of the mussel Mytilus edulis L. Comp Biochem Physiol C Pharmacol Toxicol Endocrinol 113:267

Kim D (2001) Seasonality of marine algae and grazers of the Antarctic rocky intertidal, with emphasis on the role of the limpet Nacella concinna Strebel (Gastropoda: Patellidae). University of Bremen

Kluytmans JH, de Bont AMT, Janus J, Wijsman TCM (1977) Time dependent change and tissues specificities in the accumulation of anaerobic endproducts in the sea mussel, Mytilus edulis L. Comp Biochem Physiol 58B:81-87

Lazzarino G, Amorini AM, Fazzina G, Vagnozzi R and others (2003) Single-sample preparation for simultaneous cellular redox and energy state determination. Anal Biochem 322:51-59

Lowell RB (1984) Desiccation of intertidal limpets: effects of shell size, fit to substratum, and shape. J Exp Mar Biol Ecol 77:197-207

Massabuau JC (2001) From low arterial- to low tissueoxygenation strategy. An evolutionary theory. Respir Physiol 128:249-261

Massabuau JC (2003) Primitive, and protective, our cellular oxygenation status? Mech Ageing Dev 124:857-863

McMahon RF (1988) Respiratory response to periodic emergence in intertidal molluscs. Am Zool 28:97-114

Nicchitta CV, Ellington WR (1983) Energy metabolism during air exposure and recovery in the high intertidal bivalve

Editorial responsibility: Hans Heinrich Janssen, Oldendorf/Luhe, Germany mollusc Geukensia demissa granosissima and the subtidal bivalve mollusc Modiolus squamosus. Biol Bull (Woods Hole) 165:708-722

Orton JH (1932) Studies on the relation between organism and environment. Proc Trans Liverpool Biol Soc 46:1-16

Pörtner HO, Boutilier RG, Tang Y, Toews DP (1990) Determination of intracellular $\mathrm{pH}$ and $\mathrm{PCO}_{2}$ after metabolic inhibition by fluoride and nitrilotriacetic acid. Respir Physiol 81: 255-274

Pörtner HO, Peck L, Zielinski S, Conway LZ (1999) Intracellular $\mathrm{pH}$ and energy metabolism in the highly stenothermal Antarctic bivalve Limopsis marionensis as a function of ambient temperature. Polar Biol 22:17

Schloss IR, Ferreyra GA, González O, Atencio A and others (2008) Long term hydrographic conditions and climate trends in Potter Cove. In: Wiencke C, Ferreyra, GA, Abele D, Marenssi S (eds) The Antarctic ecosystem of Potter Cove, King-George Island (Isla 25 de Mayo), Vol 571. Reports Polar and Marine Research, Bremerhaven, p 382-389

Sidell BD, Driedzic WR, Stowe DB, Johnston IA (1987) Biochemical correlations of power development and metabolic fuel preference in fish hearts. Physiol Zool 60:221-232

- Silva MP, Favero M, Martinez MM (1999) Prey size selectivity by kelp gulls on Antarctic limpets at King George Island, Antarctica. Polar Biol 21:397-400

Sokal RR, Rohlf FJ (1995) Biometry: the principles and practice of statistics in biological research. Freeman \& Co., New York

Sokolova IM, Pörtner HO (2001) Physiological adaptations to high intertidal life involve improved water conservation abilities and metabolic rate depression in Littorina saxatilis. Mar Ecol Prog Ser 224:171-186

Stanwell-Smith D, Clarke A (1998) The timing of reproduction in the Antarctic limpet Nacella concinna (Strebel, 1908) (Patellidae) at Signy Island, in relation to environmental variables. J Molluscan Stud 64:123-127

Tielens AGM, Rotte C, van Hellemond JJ, Martin W (2002) Mitochondria as we don't know them. Trends Biochem Sci 27:564-572

> Truchot JP (1990) Respiratory and ionic regulation in invertebrates exposed to both water and air. Annu Rev Physiol 52:61-74

Turner J, Colwell SR, Marshall GJ, Lachlan-Cope TA and others (2005) Antarctic climate change during the last 50 years. Int J Climatol 25:279-294

Walker AJM (1972) Introduction to the ecology of the Antarctic limpet Patinigera polaris at Signy Island, South Orkney Islands. Br Antarct Surv Bull 28:49-69

- Wallace LR (1972) Some factors affecting vertical distribution and resistance to desiccation in the limpet, Acmaea testudinalis (Muller). Biol Bull 142:186

Waller C, Worland M, Convey P, Barnes D (2006) Ecophysiological strategies of Antarctic intertidal invertebrates faced with freezing stress. Polar Biol 29:1077

> Wolcott TG (1973) Physiological ecology and intertidal zonation in limpets (Acmaea): a critical look at limiting factors. Biol Bull 145:389

Zacher K, Hanelt D, Wiencke C, Wulff A (2007) Grazer and UV radiation effects on an Antarctic intertidal microalgal assemblage: a long-term field study. Polar Biol 30: $1203-1212$

Submitted: June 19, 2008; Accepted: October 16, 2008 Proofs received from author(s): November 19, 2008 